B I O S C I E N C E

J O U R N A L

\title{
ORGANIC FERTILIZATION AS AN ALTERNATIVE TO THE \\ CHEMICAL IN CHERRY TOMATO GROWING UNDER IRRIGATION DEPTHS
}

\begin{abstract}
Rigoberto Moreira de MATOS ${ }^{1}$ (D), Patrícia Ferreira da SILVA² ${ }^{2}$, José DANTAS NETO ${ }^{3}$ iD, Antônio Suassuna de LIMA ${ }^{1}$ iD, Vera Lúcia Antunes de LIMA $^{3}$ iD, Luciano Marcelo Fallé SABOYA ${ }^{3}$

1 Postgraduate Program in Agricultural Engineering, Federal University of Campina Grande, Campina Grande, Paraíba, Brazil.
2 Postdoctoral in Engineering and Resource Management, Federal University of Campina Grande, Campina Grande, Paraíba, Brazil.
${ }^{3}$ Department of Agricultural Engineering, Federal University of Campina Grande, Campina Grande, Paraíba, Brazil.

Corresponding author:

Patrícia Ferreira da Silva

Email: patrycyafs@yahoo.com.br
\end{abstract}

How to cite: MATOS, R.M., et al. Organic fertilization as an alternative to the chemical in cherry tomato growing under irrigation depths. Bioscience Journal. 2021, 37, e37006. https://doi.org/10.14393/BJ-v37n0a2021-48270

\begin{abstract}
Two experiments were carried out to evaluate the effects of organic fertilization as an alternative to the chemical on the yield and quality of cherry tomato grown under different irrigation depths in protected environment, in 2013 and 2014. The experimental design was in randomized blocks ( $5 \times 3$ factor), with five irrigation depths as the factors (70\%, 85\%, 100\%, $115 \%$ and $130 \%$ of ETc) and three types of fertilization: no fertilized soil (control), NPK fertilized soil (Chemical) and earthworm humus fertilized soil (organic). The following were evaluated in this study: water use efficiency, number of aborted flowers, total soluble solid content, transverse and longitudinal diameter of the fruits, number of fruits and fruit yield per plant. Organic fertilization is an alternative to the chemical with no losses in yield and fruit quality. The increase in water depth enhanced yield and fruit diameters and reduced water use efficiency. Water use efficiency was more sensitive to the increments in water depth than to different types of fertilization. The values of ${ }^{\circ} \mathrm{Brix}$ obtained in the experiment were classified as acceptable for the domestic and international market when submitted to organic fertilization.
\end{abstract}

Keywords: Chemical and Organic Fertilizer. Solanum lycopersicum L. Water Deficit.

\section{Introduction}

The cherry tomato (Solanum lycopersicum L. var. cerasiforme) is highly accepted in its fresh form by the consumer market and is considered a gourmet product, with increasing demand by the producers due to the compensating values and for presenting a high market profit which is attributable to its good rusticity, pest and disease tolerance and high yields (Medeiros et al. 2011; Preczenhak et al. 2014). Red cherry tomatoes have typically autogenous and generally undetermined growth plants that are resistant to pests and diseases with 15 to 50 fruits by bunch, these are small and can be round or long, weighing between 10 and 30g (Preczenhak et al. 2014). In addition, the fruit presents longer shelf life of approximately 18 days after harvesting so it can be grown in small areas reaching high yields with excellent financial return.

Silva et al. (2013) state that to obtain valid yields and, consequently, superior economic returns with tomato, it is essential to adopt new technologies, such as the proper management of mineral nutrition, whether through organic or chemical fertilization, water supply and cultivation in a protected environment. The continuous addition of chemical fertilizers is one of the major obstacles in tomato cultivation, due to the high cost despite the overall increase in production, it has damaged the ecological system of farming lands, 
the quality and taste of the products are inferior as well as it has contributed to the increase in risks for the environment and the health of the final consumer (Silva et al. 2011).

Hence, the use of organic fertilizers as an alternative to the chemical in tomato crops has resulted in excellent yields and fruit quality and when used in the crop. Moreover, it also contributes to the reduction in production costs, according to the absorption rate of the vegetables. In addition, consumers recognize that products obtained from organic production are safe, free of chemical residues and present high nutritional value (Pinho et al. 2011). Mueller et al. (2013) report that organic fertilization constitutes an excellent soil conditioner, improves soil fertility and its physical, chemical, biological and water characteristics, and has potentiated crop productivity.

Fertilization strategies associated with water saving irrigation may allow the optimization of crop water productivity by stabilizing yield and improving product quality. These crop irrigation management strategies should consider crop specificities, crop evapotranspiration, weather, water availability and type of soil (Patanè et al. 2011). According to Santana et al. (2010), the study of a suitable water depth for cultivation is responsible for affecting tomato yield and quality, since this crop responds negatively to excess as well as to soil moisture deficit. When the irrigation technique is properly applied, it presents great potential to enhance the water use efficiency, promoting the maximum yield and also the increase in fruit quality parameters, such as sugar content (Monte et al. 2013).

The production of tomato under adequate water depth combined with organic fertilization can be considered a good opportunity of investment for the farmer; however, studies that associate the application of the water depth to different types of fertilization in the cherry tomato production in protected environment are scarce, regarding the rational use of water in the semi-arid region, in face of water scarcity and the substitution of conventional farming systems by organic system. The objective of this study was to evaluate the effects of organic fertilization as an alternative to the chemical on the yield and quality of the cherry tomato grown under different irrigation depths in the protected environment.

\section{Material and Methods}

The experiment was carried out in an experimental area of the Universidade Federal de Campina

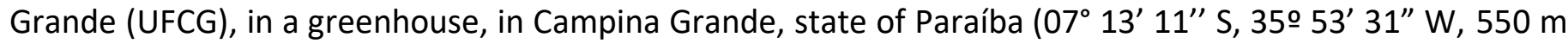
above sea level). The study was made up of two experiments; experiment I started in May and ended in August 2013 and the experiment II, started in June and ended in October 2014.

The tomato cultivar used in this study was red cherry, its characteristics are globular fruits weighing between 18 and 25g, resistant to pests and diseases, harvesting starting at 95 days and extending for 90 days after transplanting, of undetermined growth and high yield were used. The seedlings were produced in expanded polyethylene trays of 128 cells, filled with commercial substrate, using two seeds per cell. Transplanting was carried out using two seedlings per pot, when they presented four definitive leaves, at 25 days after sowing. Because tomato is an herbaceous and flexible stem plant, the plants were trained upwards with vertical strings to avoid contact with the soil and reduce phytosanitary problems. Phytosanitary control was carried out to prevent the appearance and proliferation of pests and diseases.

Each experiment consisted of five rows of 15 pots, with a diameter of $0.30 \mathrm{~m}$, volume of $22.5 \mathrm{~L}$, spaced between $0.5 \mathrm{~m}$ between pots and $1.0 \mathrm{~m}$ between pot rows. It was used a randomized block design and $5 \times 3$ factorial scheme, where two factors were combined: water depths and types of fertilization. For water depths, decimal fraction and five levels of crop evapotranspiration - ETc (Fraction (F) of 70\%, 85\%, $100 \%, 115 \%$ and $130 \%$ of the ETc) were used for the water depths. For fertilization type factor, three types were used: no fertilized soil (Control), NPK fertilized soil (Chemical fertilization: Urea, Simple Superphosphate and Potassium Chloride) based on the recommendations of Novais et al. (2007) and fertilized with earthworm humus (Organic Fertilization) based on the recommendation of Maia et al. (2013), with five replications, totaling 75 experimental plots.

Regarding experiment $\mathrm{I}$, in the treatments with chemical fertilization (NPK), $2.33 \mathrm{~g}$ of $\mathrm{N} ; 1.35 \mathrm{~g}$ of $\mathrm{P}$; $4.20 \mathrm{~g}$ of $\mathrm{K}$ were applied in foundation fertilization and in the treatments with organic fertilization, $2 \mathrm{~L}$ of earthworm humus were applied per experimental plot. In the experiment II, in treatments with chemical fertilization (NPK), as much as twice of the amount applied in experiment I was distributed, as follows: 0.306 $\mathrm{g}$ of $\mathrm{N} ; 2.70 \mathrm{~g}$ of $\mathrm{P} ; 1.68 \mathrm{~g}$ of $\mathrm{K}$ applied to the foundation and the rest of the fertilization was split into four 
seasons: at 15, 30, 45 and 60 Days after Transplanting (DAT), at the following doses: $1.09 \mathrm{~g} \mathrm{~N} ; 1.68 \mathrm{~g}$ of $\mathrm{K}$, totaling: $4.66 \mathrm{~g}$ of $\mathrm{N} ; 2.70 \mathrm{~g}$ of $\mathrm{P} ; 8.40 \mathrm{~g}$ of $\mathrm{K}$, and the simple superphosphate was completely applied in the foundation fertilization. In the organic fertilization treatments, $4 \mathrm{~L}$ of humus were applied per plot, where $0.8 \mathrm{~L}$ was distributed in the foundation and the others split in four seasons at 15, 30, 45 and 60 DAT.

The soil used in the study was classified as a sandy-loam texture, whose physical and chemical characteristics in the 0.0-0.2 m layer are found in Table 1, according to methodology of Embrapa (2013).

The chemical and fertility characteristics of the organic fertilizer (earthworm humus) used in the study are shown in Table 2.

Table 1. Characteristics of the physical and chemical the soil used in the experiment.

\begin{tabular}{|c|c|c|c|c|c|c|c|c|c|}
\hline $\mathrm{pH}$ & OM & $\mathrm{P}$ & $S$ & $\mathrm{~K}$ & $\mathrm{Na}$ & $\mathrm{Ca}$ & $\mathrm{Mg}$ & Al & $\mathrm{H}$ \\
\hline & -- \% -- & \multicolumn{2}{|c|}{$-m g / 100 g-$} & \multicolumn{6}{|c|}{-------------------- $\mathrm{mmol}_{\mathrm{c}} \mathrm{dm}^{-3}$} \\
\hline \multirow[t]{4}{*}{7.04} & 0.96 & 3.50 & 7.10 & 0.25 & 0.20 & 3.55 & 3.10 & 0.00 & 0.00 \\
\hline & \multicolumn{2}{|c|}{ Density } & & Sand & & Silt & & Clay & \\
\hline & \multicolumn{2}{|c|}{$---\mathrm{g} \mathrm{cm}^{-3}---$} & & \multicolumn{6}{|c|}{----------------------- (\%) ---------------------- } \\
\hline & & 1.33 & & 85.1 & & 8.0 & & 6.9 & \\
\hline
\end{tabular}

${ }^{*} \mathrm{pH}$ - Hydrogen potential; OM - Organic matter; P - Phosphorus; S - Súlfur; K - Potassium; Na - Sodium; Ca - Calcium; Mg Magnesium; Al - Aluminum and $\mathrm{H}$ - Hydrogen.

Table 2. Characteristics of the organic fertilizer (earthworm humus) used in the experiment.

\begin{tabular}{|c|c|c|c|c|c|c|c|c|c|c|c|c|}
\hline $\mathrm{pH}$ & $P$ & $\mathrm{~K}$ & $\mathrm{Na}$ & $\mathrm{Ca}$ & $\mathrm{Mg}$ & $\mathrm{Al}$ & $\mathrm{H}+\mathrm{Al}$ & SB & CEC & V & $\mathrm{m}$ & OM \\
\hline & --- $\mathrm{mg} \mathrm{d}$ & $n^{-3}---$ & $-\cdots$ & - & $\mathrm{cm}$ & $I_{c} \mathrm{dm}$ & - & -- & & $---\%$ & & $\mathrm{~g} \mathrm{~kg}^{-1}$ \\
\hline 7.7 & 1658.0 & 2356.0 & 4.4 & 14.3 & 9.3 & 0.0 & 0.0 & 34.1 & 34.1 & 100.0 & 0.0 & 234.1 \\
\hline
\end{tabular}

$* \mathrm{pH}$ - Hydrogen potential; P - Phosphorus; K - Potassium; Na - Sodium; Ca - Calcium; Mg - Magnesium; Al - Aluminum; $\mathrm{H}+\mathrm{Al}$ Hydrogen + aluminum; SB - Sum of bases; CEC - Cation exchange capacity; $V$ - Saturation by bases; $m$ - Saturation by aluminum and OM - Organic matter.

Everyday evaporation Class-A tank, installed within the protected environment was determined daily and multiplied by a coefficient (Kp) equal to 1.0, as recommended by Fernandes et al. (2004) to estimate the reference evapotranspiration (ETo). In both experiments, irrigation management was carried out based on crop evapotranspiration (ETc), whose value was obtained by multiplying the ETo by the tomato crop coefficient $(\mathrm{Kc})$ for each growth phase. The values of Kc for tomato were used for protected environment, according to Reis et al. (2009).

The irrigation depths daily applied was calculated by considering the decimal fraction of the crop evapotranspiration, according to each treatment $(F)$, the area of the pot $\left(S=70.650 \mathrm{~mm}^{2}\right)$ and efficiency of the irrigation system $(\mathrm{Ei}=0.93)$, according to Eq. 1:

$$
I D=0,076 * F * E T c
$$

Where: ID = irrigation depths applied in each treatment $\left(\mathrm{mm} \mathrm{d}^{-1}\right) ; 0.077=\left(\left(70.650 \mathrm{~mm}^{2} \times 10^{-6}\right) / 0.93\right)$; $\mathrm{F}=$ decimal fraction of crop evapotranspiration, according to each treatment; $\mathrm{ETc}=$ crop evapotranspiration $\left(\mathrm{mm}\right.$ day $\left.^{-1}\right)$.

The experiment used the drip irrigation system with compensating type emitters, pressurized by a centrifugal engine-pump set with power of $0.5 \mathrm{hp}$ and flow capacity of $2.160 \mathrm{~L} \mathrm{~h}^{-1}$. The flow test was performed in each of the 75 installed emitters, which presented an average flow of $2.1 \mathrm{~L} \mathrm{~h}^{-1}$. The control head consisted of a 1" screen filter, with a capacity of $5.0 \mathrm{~m}^{3} \mathrm{~h}^{-1}$, a Bourdon type pressure gauge, pressure/flow control valves and solenoid valves to drive each operating unit of the system.

To evaluate the sources of variation, irrigation depths as a function of crop evapotranspiration - ETc and types of fertilization were analyzed during the production phase. Water use efficiency was calculated by relating the total production per plant with the leaf of irrigation applied to each plant, according to Guan et al. (2015), Eq. 2: 


$$
W U E=\frac{Y}{I D}
$$

Where: WUE = water use efficiency $\left(\mathrm{kg} \mathrm{m}^{-3}\right) ; \mathrm{Y}=$ cherry tomato total yield $(\mathrm{kg}) ; \mathrm{ID}=$ irrigation depth applied throughout the cycle $\left(\mathrm{m}^{-3}\right)$.

The following were also evaluated: the number of aborted flowers, obtained by the difference between the number of flowers and the number of fruits harvested; total soluble solids content ( ${ }^{\circ}$ Brix) of the fruits was determined in the laboratory, with the aid of a refractometer; the transversal and longitudinal diameters of the fruits obtained with digital caliper; the number of fruits per plant, through the direct counting of the fruits in each plant; and fruit yield per plant, based on the number and mass of the fruits, discarding the non-marketable fruits.

The variables were statistically analyzed using the $F$ test at the 1 and $5 \%$ level of probability. Significant variables were submitted to polynomial regression (linear and quadratic) for the irrigation depth quantitative factor. For the fertilization type qualitative factor, the test of Tukey for mean comparison was applied at 5\%. The analyzes were performed using the statistical software Sisvar (Ferreira 2014).

\section{Results}

The summary of the analysis of variance for the water use efficiency (WUE), number of aborted flowers, total soluble solids content ( ${ }^{\circ}$ Brix), transverse diameter of fruits, longitudinal diameter of fruits, number of fruits per plant end yield for experiment I and II, is in Table 3. Significant effect of irrigation depth at $1 \%$ probability level was observed by the $\mathrm{F}$ test for water use efficiency and fruit cross-sectional diameter, experiment I (Table 3). There was a significant effect of type the fertilization on the variables water use efficiency (WUE), number of aborted flowers, total soluble solids content ( ${ }^{\circ}$ Brix) $(p<0.01)$ and for transverse diameter of fruits, longitudinal diameter of fruits, number of fruits per plant end yield there was no significance for the type the fertilization in experiment I (Table 3). For Experiment I the interaction was significant at a $1 \%$ probability level for the number of fruits per plant end yield, respectively (Table 3 ).

It was verified that for experiment II there was effect of irrigation depth at $1 \%$ level for water use efficiency and longitudinal diameter of fruits, respectively. There was also a significant effect $(p<0.01)$ of the type of fertilization for all variables analyzed. There was no significant interaction between the factors studied in any of the variables analyzed in experiment II (Table 3 ).

In experiment I, production occurred until 96 DAT, during this period, the following volumes of water were applied: $241.6 ; 293.4 ; 345.2 ; 397.0$ and $448.7 \mathrm{~mm}$ per cycle, for the irrigation depths of $70,85,100$, 115 and $130 \%$ of ETc, respectively.

For experiment II, production occurred until 120 DAT, where the following volumes of water were applied: 327.8; 398.0; 468.3; 538.5 and $608.7 \mathrm{~mm}$ per cycle, for irrigation depths of 70, 85, 100, 115 and $130 \%$ of ETc, respectively.

Water use efficiency of "cherry" tomatoes was significantly influenced by the isolated effect of the irrigation depths and the types of fertilization in experiments I and II (Figures $1 \mathrm{~A}$ and B).

The maximum water use efficiency in experiment I was achieved in the irrigation depth of $103.5 \%$ ETc (8.2 $\mathrm{kg}$ of tomato per $\mathrm{m}^{-3}$ of water). In experiment II, there was a decrease by increment in the irrigation blade, with a maximum water efficiency in $70 \%$ ETc $\left(16.6 \mathrm{~kg} \mathrm{~m}^{-3}\right)$ and a minimum of $130 \%$ of ETc $\left(9.9 \mathrm{~kg} \mathrm{~m}^{-}\right.$ $\left.{ }^{3}\right)$, Figure $1 \mathrm{~A}$.

A significant effect was observed by Tukey's test at $5 \%$ of probability of fertilization types on water use efficiency for experiments I and II (Figure 1B). In the experiment I, the treatment with organic fertilizer evidenced the highest water use efficiency $\left(9.8 \mathrm{~kg} \mathrm{~m}^{-3}\right)$ whereas the treatments with chemical $\left(18.0 \mathrm{~kg} \mathrm{~m}^{-3}\right)$ and organic (17.5 $\mathrm{kg} \mathrm{kg} \mathrm{m}^{-3}$ ) fertilization in experiment II provided the greatest water use efficiencies in tomato plants. This fact possibly occurs as a result of organic fertilizer providing improvements in soil fertility, as well as in its physical and biological characteristics.

The number of aborted flowers per plant and the total soluble solids content ( ${ }^{\circ} \mathrm{Brix}$ ) of cherry tomato was significantly influenced only by the isolated effect of the types of fertilization in experiments I and II (Figures $2 \mathrm{~A}$ and $\mathrm{B}$ ). 
Table 3. Summary of the analysis of variance for water use efficiency (WUE), number of aborted flowers, total soluble solids content ( ${ }^{\circ} \mathrm{Brix}$ ), transverse diameter of fruits, longitudinal diameter of fruits, number of fruits per plant end yield for experiment I and II of red cherry tomatoes under different irrigation depths and of organic fertilization and chemical in the protected environment.

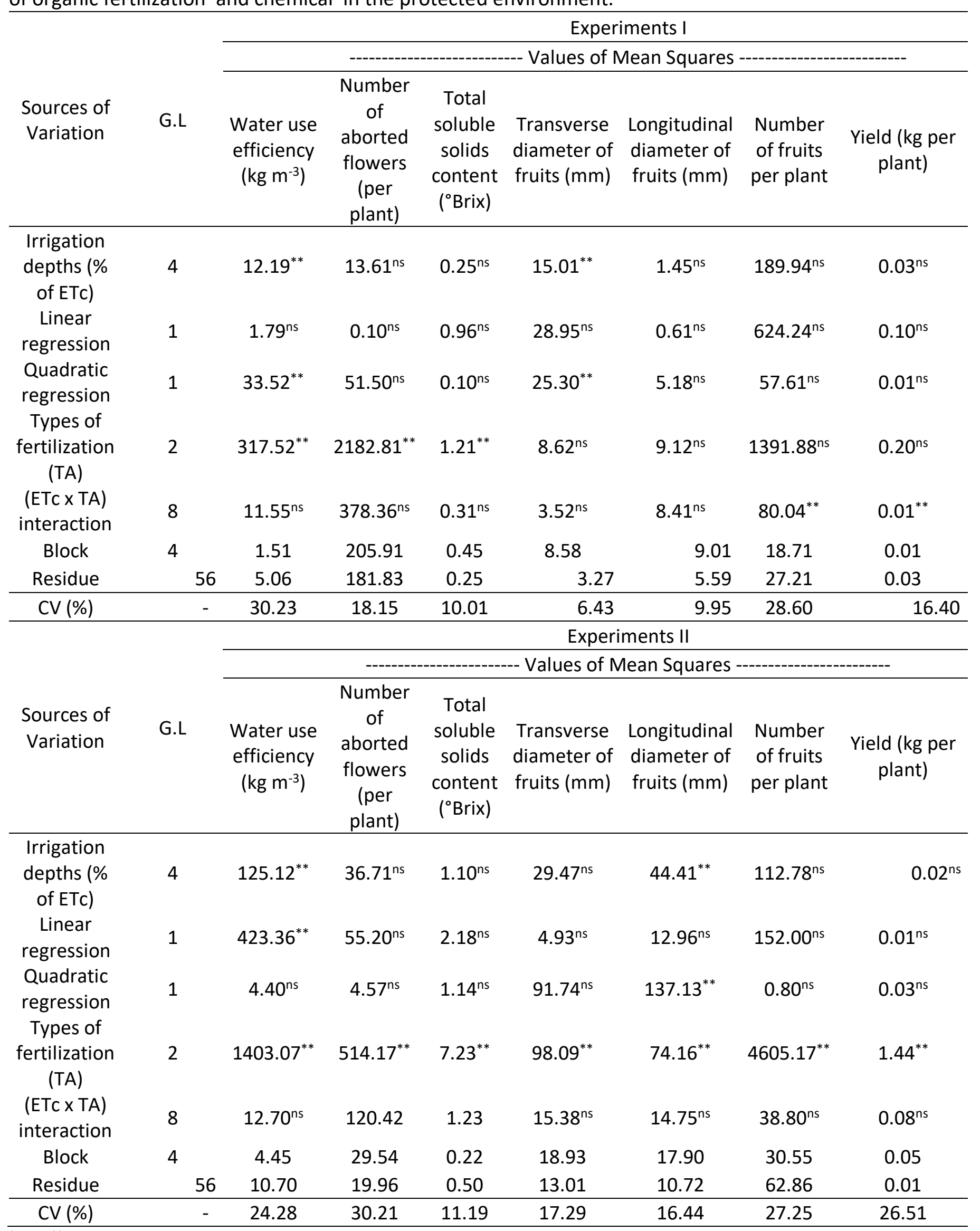

${ }^{*}$ and ${ }^{* *}$ means 5 and $1 \%$ of probability, respectively; ${ }^{\text {ns }}$ means not significant. 
(A)

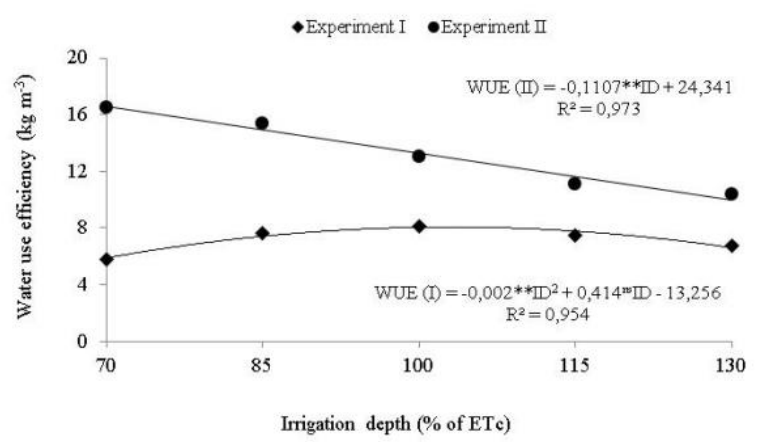

(B)

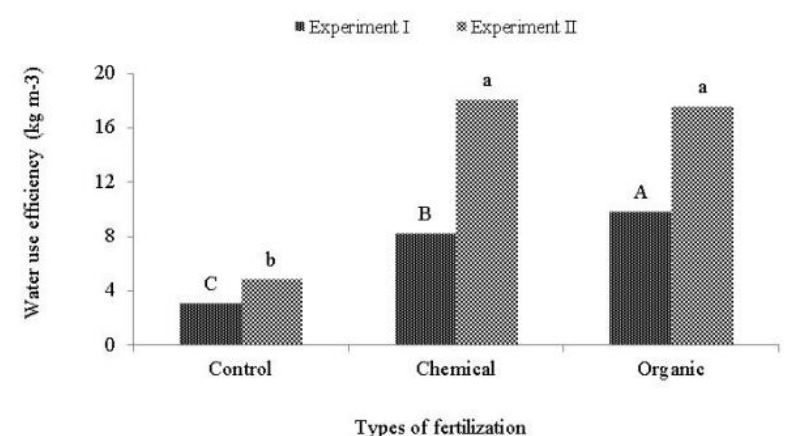

Figure 1. Water use efficiency of cherry tomato as a function of irrigation depths (A) and types of fertilization (B), for experiments I and II. ${ }^{* *}$ significant at $1 \%$ for linear regression. Capital letters indicate Tukey test at 0.05 probability level for experiment I and lower case for experiment II.

(A)

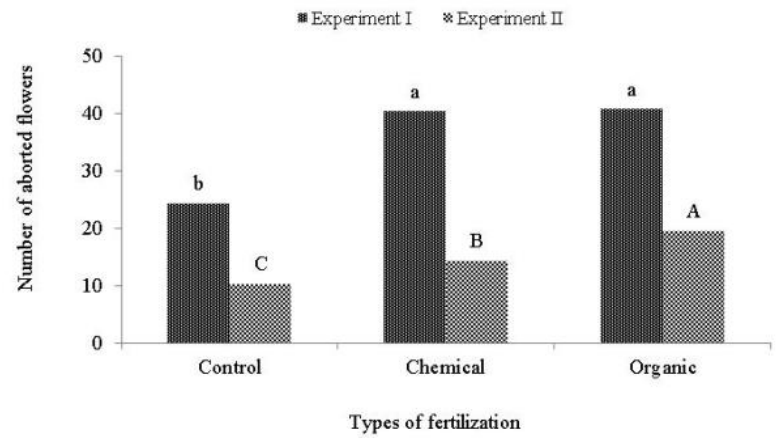

(B)

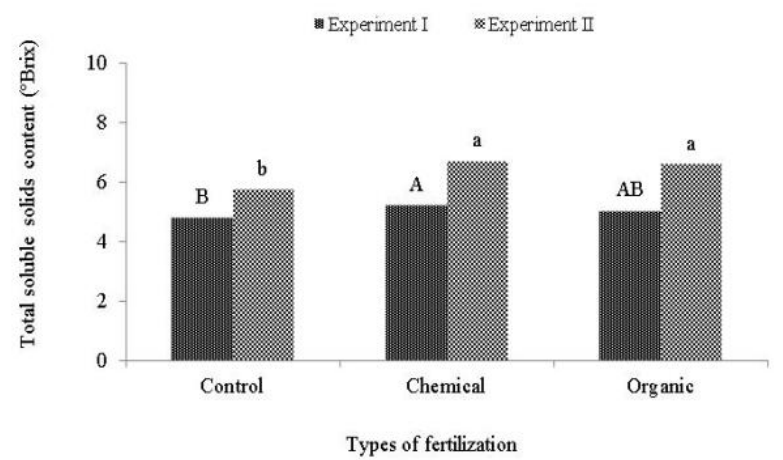

Figure 2. Number of aborted flowers (A) and total soluble solids content (B) of cherry tomatoes according to the types of fertilization, for experiments I and II. Means followed by the same letter are not different from each other by the test of Tukey at $5 \%$ of probability. Capital letters indicate Tukey test at 0.05 probability level for experiment I and lower case for experiment II.

In experiment $\mathrm{I}$, in all types of fertilization, the number of aborted flowers was higher than in experiment II, and the types of chemical and organic fertilizers statistically differed from the control. In experiment II, the largest flower abortion occurred in organic fertilization, statistically differing from the chemical and control by the test of Tukey (Figure 2A).

The highest values of the total soluble solids content were achieved in Experiment II in plants fertilized with chemical $\left(6.7^{\circ} \mathrm{Brix}\right)$ and organic $\left(6.6^{\circ} \mathrm{Brix}\right)$ fertilizer, which differed from the control $\left(5.7^{\circ} \mathrm{Brix}\right)$. In the experiment I, the total soluble solids content was lower in comparison to experiment II, and the organic fertilization $\left(5.0^{\circ} \mathrm{Brix}\right)$ did not differ from the chemical $\left(5.2^{\circ} \mathrm{Brix}\right)$ and the control $\left(4.8^{\circ} \mathrm{Brix}\right)$ by the test of Tukey (Figure 2B). Preczenhak et al. (2014) state that total soluble solids content ( ${ }^{\circ}$ Brix) values ranging from 4.25 to 10 are considered acceptable for the domestic and international markets.

The transverse diameter of cherry tomato fruit was significantly influenced by the isolated effect of the irrigation depths in experiment I and by the types of fertilization in experiment II (Figures $3 \mathrm{~A}$ and $\mathrm{B}$ ).

The transverse diameter of cherry tomato fruits in experiment I was influenced only by irrigation depths. No increase occurred in the transverse diameter of the fruits up to the irrigation depth of $107.3 \%$ ETc, with a maximum value of $27.6 \mathrm{~mm}$. From this point, a reduction occurred in the diameter of the fruits, and the increment of the irrigation depth from $70 \%$ to $107.3 \%$ ETc was $4.5 \%$ in the transverse diameter of the fruits (Figure $3 \mathrm{~A}$ ).

A significant effect was only observed in types of fertilization for the transverse diameter of cherry tomato fruits in experiment II. The largest fruit diameter was obtained in the treatment with application of organic fertilization $(22.8 \mathrm{~mm})$ followed by chemical fertilization $(20.9 \mathrm{~mm})$ and the shortest transverse 
diameter was evidenced by the control $(18.8 \mathrm{~mm})$. The organic treatment did not differ from the chemical; it differed only from the control by the test of Tukey (Figure 3B).

The longitudinal diameter of cherry tomato fruit was significantly influenced in isolation by the irrigation depths and by the types of fertilization only in experiment II (Figures 4A and B).

(A)

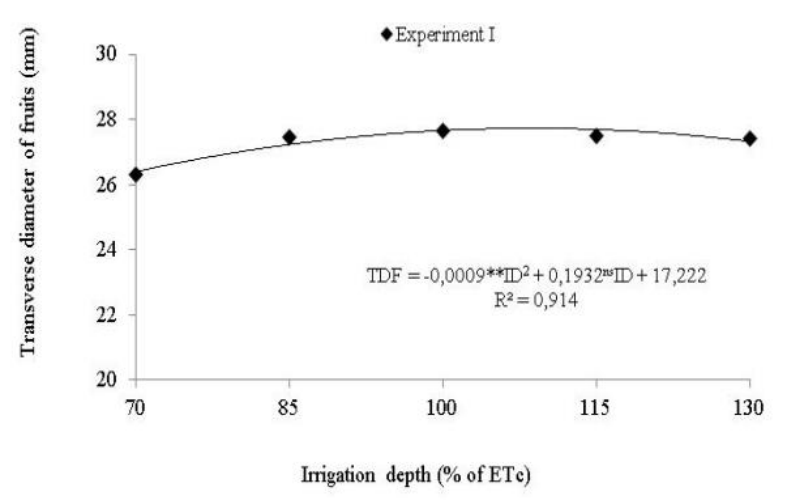

(B)

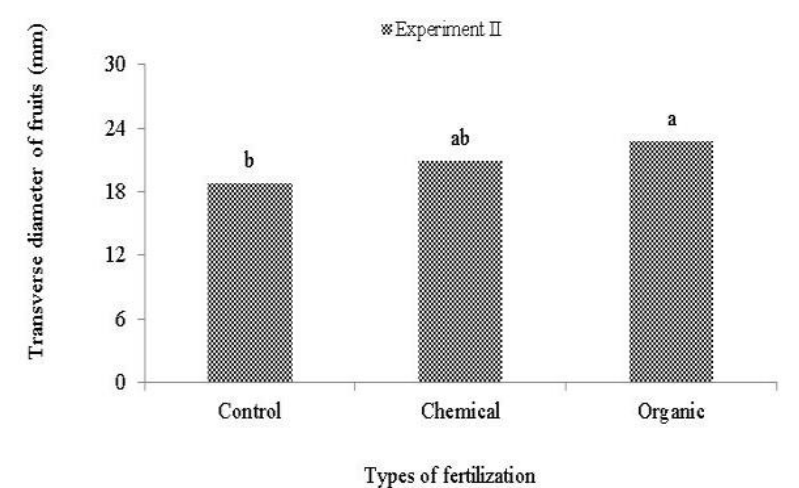

Figure 3. Transverse diameter of "cherry" tomato fruit as a function of the irrigation depths for experiment I (A) and fertilization types for experiment II (B). ** significant at $1 \%$ for linear regression.

(A)

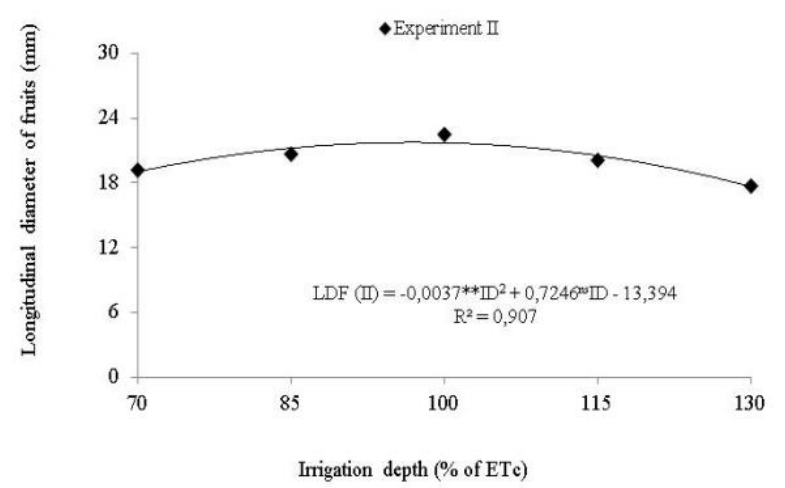

(B)

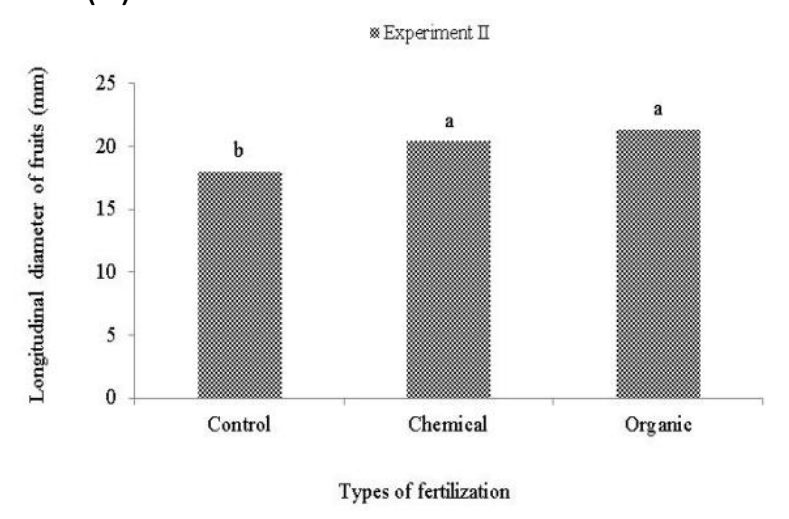

Figure 4. Longitudinal diameter of cherry tomato fruits according to the irrigation depths $(A)$ and fertilization types (B), for experiment II. ${ }^{* *}$ significant at $1 \%$ for linear regression.

An increment occurred in the longitudinal diameter of fruits as irrigation depth was increased up to 97.9\% of the ETc. From this point, the increase in the irrigation depth decreased the diameter of the fruits. The largest longitudinal diameter of fruits was $22.1 \mathrm{~mm}$ and the lowest was $18.3 \mathrm{~mm}$ obtained in irrigation depths of $97.9 \%$ and $130 \%$ of ETc, respectively (Figure $4 \mathrm{~A}$ ).

The types of fertilization statistically differed at the $5 \%$ level by the test of Tukey for the longitudinal diameter of cherry tomato fruit, and treatments with chemical $(20.4 \mathrm{~mm})$ and organic $(21.3 \mathrm{~mm})$ fertilization showed the largest longitudinal diameter of fruits, which differed them from the control treatment (18.0 $\mathrm{mm}$ ) (Figure 4B).

It can be observed that red cherry tomatoes were classified as round because the longitudinal diameter was less than or equal to the transverse diameter of the fruits (Figures 3 and 4).

Fruit number per cherry tomato plant in experiment I was influenced only by the interaction between organic fertilization within the irrigation depths whereas in experiment II, an isolated effect of fertilization types was observed (Figures $5 \mathrm{~A}$ and $\mathrm{B}$ ).

The linear mathematical model was the one that best fit the number of fruits per plant, where the smallest number of fruits was obtained in the water depth of $70 \%$ and the highest with $130 \%$ of the ETc, corresponding to 11.6 and 30.8 fruits per plant, respectively. At every $15 \%$ increase in irrigation depth, an increase of 4.7 fruits per plant occurred (Figure $5 \mathrm{~A}$ ). 
A significant effect of only the fertilization type under the number of fruits per plants was observed in experiment II. The treatments with chemical (38.4 fruits) and organic fertilization (35.9 fruits) did not differ statistically among themselves by the test of Tukey at $5 \%$ probability, differing only from the control treatment (13.5 fruits), Figure 5B.

The cherry tomato yield in experiment I was influenced only by the interaction between organic fertilization within the water depths whereas in experiment II, an isolated effect of fertilization types was observed (Figures $6 \mathrm{~A}$ and $\mathrm{B}$ ).

(A)

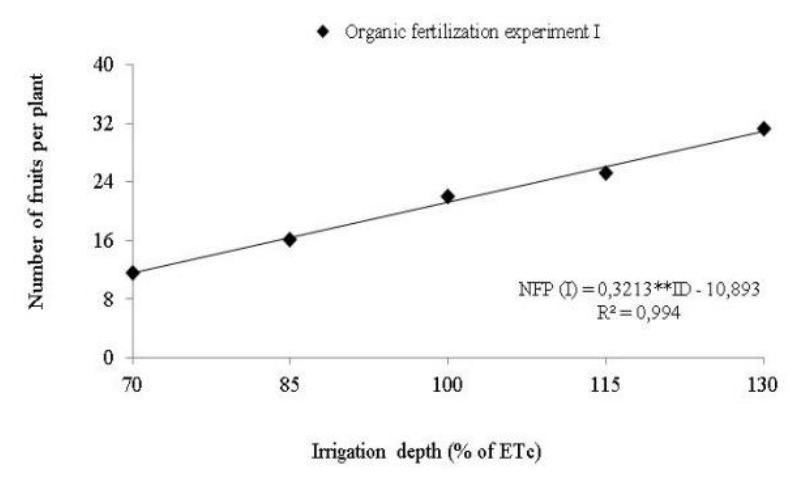

(B)

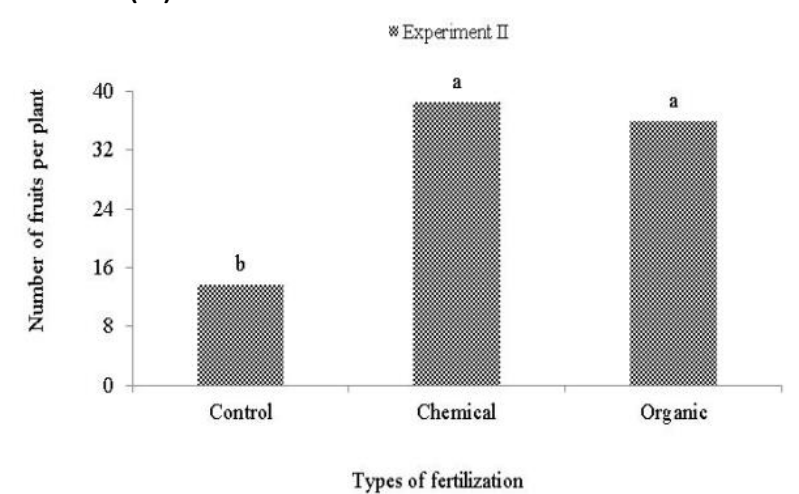

Figure 5. Number of fruits per cherry tomato plant as a function of the interaction between irrigation depths and organic fertilization for the experiment I (A) and the types of fertilization for experiment II (B). $* *$ significant at $1 \%$ for linear regression.

(A)

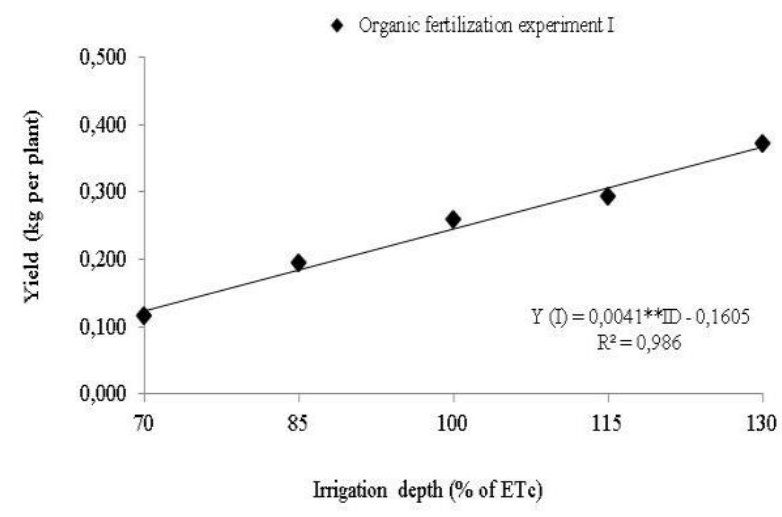

(B)

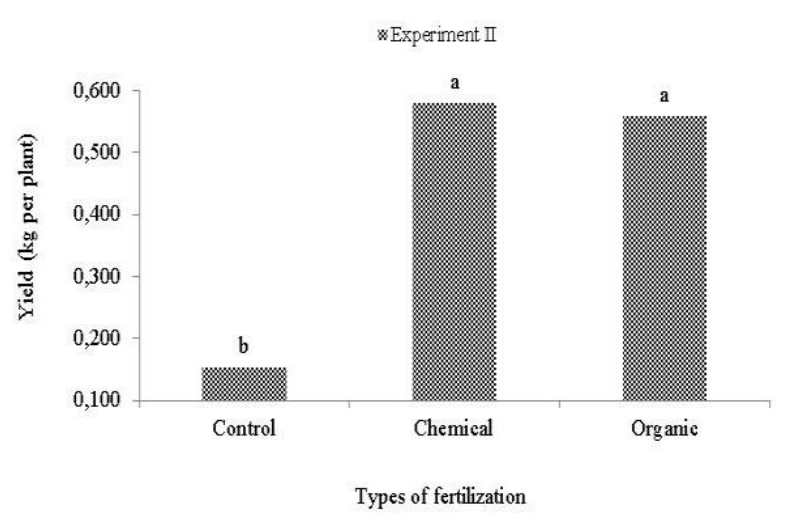

Figure 6. "Cherry" tomato yield as a function of the interaction between irrigation depths and organic fertilization for experiment I (A) and fertilization types for experiment II (B). ** significant at $1 \%$ for linear regression.

A rise was observed in the yield of cherry tomatoes for experiment I as the irrigation depth increased, with maximum yield achieved in $130 \%$ of the ETc, corresponding to $0.372 \mathrm{~kg}$ per plant, where a difference of $0.246 \mathrm{~kg}$ per plant is seen between the irrigation depth of $70 \%$ and $130 \%$ of ETc. (Figure $6 \mathrm{~A}$ ).

The highest yield and the maximum number of fruits were observed in the irrigation depth of $130 \%$ of ETc, while the greatest longitudinal and transverse diameter of the fruits were verified in the irrigation depth of approximately $100 \%$ of ETc, and the maximum efficiency of use of the water in the $70 \%$ ETc depth.

A significant effect of the fertilizer types was only observed on cherry tomato yield. The chemical treatment $(0.579 \mathrm{~kg}$ per plant) did not differ from the organic $(0.557 \mathrm{~kg}$ per plant), it only differed from the control treatment $(0.152 \mathrm{~kg}$ per plant). Such results are similar to those observed for fruit number, longitudinal and transverse fruit diameter; total soluble solids content and water use efficiency, in which the chemical fertilization did not differ from the organic by the test of Tukey (Figure 6B). 


\section{Discussion}

Silva et al. (2013) obtained water consumption of the tomato plant of $504 \mathrm{~mm}$ in protected environment at 90 DAT, using the irrigation depth at $100 \%$ of ETc. In turn, Duarte et al. (2010) determined the water consumption of the tomato of $477 \mathrm{~mm}$ in protected environment, irrigating $100 \%$ of ETc at 88 days of cultivation. In addition, Gomes et al. (2017), when studying the cultivation of tomatoes fertilized with ash and castor pie under irrigation depth, obtained a better result at the irrigation depth of $213 \mathrm{~mm}$ at 120 DAT.

It is observed that these irrigation depths are different from those quantified in the present study for $100 \%$ ETc. These differences in water consumption are likely to be attributed to the edaphoclimatic conditions of the regions where the studies were conducted and to the genetic characteristics of the cultivars used in the studies (Mello et al. 2018).

Santana et al. (2010) reported a decreasing linear effect as irrigation depth was incremented under the water use efficiency by the Andréa tomato hybrid since the increment in water availability may result in a reduction in water use efficiency. Wang and Xing (2017) observed that water use efficiency significantly reduced as irrigation depth increased. The results of these authors reinforce the data obtained in the present study.

When submitted to a mild water stress, tomato plants display a slight closure of the stomata, thus reducing transpiration more than photosynthesis and consequently, increasing water use efficiency (Favati et al. 2009; Patanè et al. 2011; Chen et al. 2013; Cantore et al. 2016). Such fact may have provided greater water use efficiency in plants at smaller water depths.

In addition, both organic and chemical fertilizers provide adequate nutrient supply to plants, especially nitrogen, favoring the synthesis of cytokines, which promotes water retention by the plant which provides greater efficiency in water use (Taiz and Zaiger 2013).

When studying the effects of irrigation and fertilization on yield and quality of tomato, Wang and Xing (2017) observed that the efficiency of water use decreased when fertilization levels were raised. This result was different from that observed in the present study since the highest water use efficiency was obtained in experiment II, which received as much as twice the amount of fertilization of experiment I.

This difference observed in the studies is linked to the amount and type of fertilizer applied to the tomato, as inadequate amounts of nitrogen may contribute to the reduction of cytokine synthesis, responsible for promoting water retention by plants. Kumar and Dey (2011) assert that the increase in uptake of nutrients such as Nitrogen, Phosphorus and Potassium provides maximum crop yield and consequently, a greater water use efficiency, thus a positive correlation between nutrient absorption and water use efficiency is observed.

Zuba et al. (2011) studied the nutrition of tomato plants under different sources of organic and chemical fertilizers and attributed the greater abortion of flowers to nutritional deficiency of plants submitted to organic fertilization. Such results are similar to those obtained in the present study where the greatest flower abortion occurred in the organic treatment. This fact is justified because cherry tomatoes do not have a strong drainage of photoassimilates, thus are vulnerable to competition for carbohydrates, as a consequence has the abortion of flowers, mainly due to the large number of flowers produced stimulated by nutrient supply of organic fertilizer.

Niedziela Junior et al. (2008) reported the occurrence of flower abortion in plants that were not fertilized with N, P and K. This justifies the fact that the experiment I resulted in a larger flower abortion, possibly because it received half the fertilization of experiment II.

Silva et al. (2011) obtained total soluble solids values ranging from 3.7 to $4.9^{\circ} \mathrm{Brix}$ when 11 rows of cherry tomatoes under organic production system were evaluated. Such values are lower than those obtained in the present study, which is possibly related to the characteristics of the lines used in the study.

The experiment II that received twice the nitrogen fertilization in relation to the experiment I, achieved the highest -Brix levels. Nitrogen plays an important role in the biosynthesis of sugars in the leaves, which can be translocated into fruits (Taiz and Zaiger 2013). The amount of soluble sugars (sucrose, glucose and fructose) determines the sweetness, quality and value of fruit commercialization (Kolayli et al. 2010).

Silva et al. (2013) obtained an increase by $57 \%$ in the transverse diameter of the tomato fruit when the water depth was increased from 33 to $166 \%$ of the ETc. Liu et al. (2013) reported that the increase in 
water depth promoted the development of tomato fruit diameters. These results restate those obtained in the present study, since the increase in the water depth increased the diameter of the fruits. Yet, Gomes et al. (2017) reported that the irrigation depths did not influence the diameter of the marketable tomato fruits. Results that differ from those obtained in the present study due to the fact that the irrigation depths are higher than this one. It is noteworthy that that excess water in the soil causes reduction of potassium absorption and nitrification, increased denitrification and nitrate leaching, and reduction of nutrient absorption and consequently fruit diameter (Santana et al. 2010).

The treatments with organic and chemical fertilizer provide larger diameters due to being rich in potassium that promotes increase in diameter, being one of the most required elements especially for performing the functions of carbohydrate translocation and regulation of stoma opening and closing. Potassium still influences tissue formation and plant respiration processes, increasing sugar content, size, weight and resistance to fruit handling (Maia et al. 2013).

These data met those obtained by Maia et al. (2013) who studied organic fertilization in tomatoes of the cherry group and observed that treatments with earthworm (organic) humus provided the largest fruit diameters when compared to the other treatments. Therefore, Zuba et al. (2011), evaluating different sources of organic and chemical fertilizers in the tomato crop did not observe any significant differences between the treatments studied for fruit diameter.

Santana et al. (2010), when studying the levels of soil water replenishment in tomato crop, reported that both the excess and the water deficit in the soil are detrimental to the productive characteristics of the tomato plants. These results are similar to those observed in the present study as the increase in the irrigation depth from $97.9 \%$ of ETc may become a water excess, decreasing the diameter of the tomato fruit, as a consequence.

Ferreira et al. (2010) claimed in their study on tomato yield as a function of nitrogen doses and organic fertilization that the fruit diameter was higher in the treatments with the application of nitrogen and organic fertilizer. This fact is similar to that observed in the present study, which is possibly related to the nutrient supply at an adequate amount to the fruit development.

Organic and chemical fertilization are sources of mineral nutrients such as phosphorus $(P)$, potassium $(\mathrm{K})$ and nitrogen $(\mathrm{N})$. It is important to highlight that $\mathrm{K}$ is closely related to fruit quality characteristics such as longitudinal and transverse diameter, texture and turgidity (Taiz and Zaiger 2013). The fruits of the control treatment presented smaller diameters, possibly due to the lack of nutrients supplied to the plants.

According to the classification of Fernandes et al. (2007), red cherry tomato falls into the medium size class, the fruits have a transverse diameter of 25 to $30 \mathrm{~mm}$ and weight ranging from 10 to $15 \mathrm{~g}$.

Patanè et al. (2011) observed that losses in tomato fruit increased as soil water deficit became greater, highlighting how irrigation in arid and semi-arid environments is important to minimize fruit losses in tomato production. These results agree with those observed in the present study as for the smaller number of fruits was observed in the lowest irrigation depth.

Maia et al. (2013) report that the organic fertilization combined with the mineral influences the action of the microorganisms present in the soil, being a great relevance for the mineralization of the organic compounds, which contributes to the supply of the nutritional demand of the crop. Marouelli et al. (2006) suggest that besides enhancing the quality of the soil by means of the nutrient supply through the mineralization of the compounds, the addition of organic fertilizers to agricultural crops contributes to enhance soil protection and to reduce water losses caused by evapotranspiration.

According to Taiz and Zeiger (2013), water deficit reduces the pressure of the cellular turgor and consequently decreases cell elongation, consequently, the growth and development of the plant. Such fact explains the lower yield obtained in the smaller irrigation depths.

Organic fertilizers increase the yield and quality of agricultural crops, provide the nutritional requirements necessary for plants in a similar way to inorganic fertilizers (chemical fertilization) (Tonfack et al. 2009; Yanar et al. 2011). This fact was observed in the results obtained in the present study, since the treatments with organic fertilization did not differ from those submitted to chemical fertilization. The not difference between treatments can be explained by the fact that organic fertilizer is rich in nutrients essential to plant development, and the tomato root system is superficial, therefore, it can absorb small nutrient 
contents in the soil which contributed to the formation organic crops as nutrients from organic compounds are slowly available.

\section{Conclusions}

Organic fertilization is able to completely replace the chemical in these cherry tomato growing conditions with no losses in the yield and fruit quality.

The increase in the water depth incremented yield and transverse and longitudinal diameters of cherry tomatoes and reduced water efficiency use.

Water use efficiency was more sensitive to increases in water depth than to the different types of fertilization.

The values of ${ }^{\circ}$ Brix obtained in both experiments were classified as acceptable for the domestic and international market when submitted to organic fertilization.

Authors' Contributions: MATOS, R.M.: conception and design, acquisition of data, analysis and interpretation of data, drafting the manuscript, final approval; SILVA, P.F.: acquisition of data, analysis and interpretation of data, drafting the manuscript, final approval; DANTAS NETO, J.: conception and design, analysis and interpretation of data, drafting the manuscript, final approval; LIMA, A.S.: analysis and interpretation of data, drafting the manuscript, final approval; LIMA, V.L.A.: acquisition of data, drafting the manuscript, final approval; SABOYA, L.M.F.: drafting the manuscript, final approval.

Conflicts of Interest: The authors declare no conflicts of interest.

Ethics Approval: Not applicable.

Acknowledgments: The authors would like to thank the funding for the realization of this study provided by the Brazilian agencies CAPES (Coordenação de Aperfeiçoamento de Pessoal de Nível Superior - Brasil), Finance Code 88882.314940/2019-01, and CNPq (Conselho Nacional de Desenvolvimento Científico e Tecnológico - Brasil), Finance Code 167674/2017-0.

\section{References}

CANTORE, V., et al. Combined effect of deficit irrigation and strobilurin application on yield, fruit quality and water use efficiency of "cherry" tomato (Solanum lycopersicum L.). Agricultural Water Management. 2016, 167(1), 53-61. https://doi.org/10.1016/i.agwat.2015.12.024

CHEN, J., et al. Quantitative response ofgreenhouse tomato yield and quality to water deficit at different growthstages. Agricultural Water Management. 2013, 129(1), 152-162. https://doi.org/10.1016/j.agwat.2013.07.011

DUARTE, G.R.B., et al. Measure and estimation of the evapotranspiration of tomato plants cultivated with organic fertilization in protected ambient. Semina: Ciências Agrárias. 2010, 31, 563-574. http://dx.doi.org/10.5433/1679-0359.2010v31n3p563

Empresa Brasileira de Pesquisa Agropecuária (EMBRAPA). Sistema brasileiro de classificação de solos. 3rd ed. Brasília: Centro Nacional de Pesquisa de Solos; Rio de Janeiro, RJ: Embrapa Solos, 2013.

FAVATI, F., et al. Processing tomato quality as affected by irrigation scheduling. Scientia Horticulturae. 2009, 122(4), 562-571.

http://dx.doi.org/10.1016/j.scienta.2009.06.026

FERNANDES, C., CORÁ, J.E. and ARAÚJO, J.A.C. Utilização do tanque Classe A para a estimativa da evapotranspiração de referência. Engenharia Agrícola. 2004, 24(1), 46-50.

http://dx.doi.org/10.1590/S0100-69162004000100006

FERNANDES, C., CORÁ, J.E. and BRAZ, L.T. Classificação de tomate-cereja em função do tamanho e peso dos frutos. Horticultura Brasileira. 2007, 25(2), 275-278. http://dx.doi.org/10.1590/S0102-05362007000200029

FERREIRA, D.F. Sisvar: a computer statistical analysis system. Ciência e Agrotecnologia. 2014, 35(6), 1039-1042. http://dx.doi.org/10.1590/S1413-70542011000600001

FERREIRA, M.M.M., FERREIRA, G.B. and FONTES, P.C.R. Eficiência da adubação nitrogenada do tomateiro em duas épocas de cultivo. Revista Ceres. 2010, 57(2), 263-273. http://dx.doi.org/10.1590/S0034-737X2010000200019

GOMES, D.P., et al. Growth and production of tomato fertilized with ash and castor cake and under varying water depths, cultivated in organic potponics. Acta Scientiarum. Agronomy. 2017, 39(2), 201-209. http://dx.doi.org/10.4025/actasciagron.v39i2.32547

GUAN, D.H., et al. Tillage practices effect on root distribution and water use efficiency of winter wheat under rain-fed condition in the North China Plain. Soil \& Tillage Research. 2015, 146(1), 286-295. http://dx.doi.org/10.1016/j.still.2014.09.016

KOLAYLI, S., et al. Comparative study of chemical and biochemical properties of different melon cultivars: standard, hybrid, and grafted melons. Journal of Agricultural and Food Chemistry. 2010, 58(17), 9764-9769. http://dx.doi.org/10.1021/jf102408y

KUMAR, S. and DEY, P. Effects of different mulches and irrigation methods on root growth, nutrient uptake, water-use efficiency and yield of strawberry. Scientia Horticulturae. 2011, 127(3), 318-324. http://dx.doi.org/10.1016/i.scienta.2010.10.023 
LIU, H., et al. Drip Irrigation Scheduling for Tomato Grown in Solar Greenhouse Based on Pan Evaporation in North China Plain. Journal of Integrative Agriculture. 2013, 12(1), 520-531.

http://dx.doi.org/10.1016/S2095-3119(13)60253-1

MAIA, J.T.L.S., et al. Adubação orgânica em tomateiros do grupo cereja. Revista Biotemas. 2013, 26(1), 37-44. http://dx.doi.org/10.5007/21757925.2013v26n1p37

MAROUELLI, W.A., SILVA, H.R. and MADEIRA, N.R. Uso da água e produção de tomateiro para processamento em sistema de plantio direto com palhada. Pesquisa Agropecuária Brasileira. 2006, 41(9), 1399-1404. http://dx.doi.org/10.1590/S0100-204X2006000900008

MEDEIROS, R.F., et al. Crescimento inicial do tomateiro-cereja sob irrigação com águas salinas em solo com biofertilizantes bovino. Revista Brasileira de Engenharia Agrícola e Ambiental. 2011, 15(5), 505-511. http://dx.doi.org/10.1590/S1415-43662011000500011

MELLO, G.A.B., et al. Organic cultivation of onion under castor cake fertilization and irrigation depths. Acta Scientiarum. Agronomy. 2018, 40(1), e34993. http://dx.doi.org/10.4025/actasciagron.v40i1.34993

MONTE, J.A., et al. Growth analysis and yield of tomato crop under different irrigation depths. Revista Brasileira de Engenharia Agrícola e Ambiental. 2013, 17(9), 926-931. http://dx.doi.org/10.1590/S1415-43662013000900003

MUELLER, S., et al. Produtividade de tomate sob adubação orgânica e complementação com adubos minerais. Horticultura Brasileira. 2013, 31(1), 86-92. http://dx.doi.org/10.1590/S0102-05362013000100014

NIEDZIELA JUNIOR, C.E., et al. Effects of N-P-K deficiency and temperature regime on the growth and development of Lilium longiflorum 'Nellie White' during bulb production under phytotron conditions. Scientia Horticulturae. 2008, 116(4), 430-436.

http://dx.doi.org/10.1016/i.scienta.2008.02.015

NOVAIS, R.F., et al. Fertilidade do solo. Viçosa: Sociedade Brasileira de Ciência do Solo, 2007.

PATANÈ, C., TRINGALI, S., and SORTINO, O. Effects of deficit irrigation on biomass, yield, water productivity and fruit quality of processing tomato under semi-arid Mediterranean climate conditions. Scientia Horticulturae. 2011, 129(4), 590-596.

http://dx.doi.org/10.1016/j.scienta.2011.04.030

PINHO, L., et al. Nutritional properties of cherry tomatoes harvested at different times and grown in an organic cropping. Horticultura Brasileira. 2011, 29(2), 205-211. http://dx.doi.org/10.1590/S0102-05362011000200012

PRECZENHAK, A.P., et al. Caracterização agronômica de genótipos de minitomate. Horticultura Brasileira. 2014, 32(2), 348-356. http://dx.doi.org/10.1590/S0102-05362014000300018

REIS, L.S., SOUZA, J.L. and AZEVEDO, C.A.V. Evapotranspiração e coeficiente de cultivo do tomate caqui cultivado em ambiente protegido. Revista brasileira de engenharia agrícola ambiental. 13(3), 289-296. http://dx.doi.org/10.1590/S1415-43662009000300010

SANTANA, M.J., et al. Resposta do tomateiro irrigado a níveis de reposição de água no solo. Revista Irriga. 2010, 15(4), $443-454$. http://dx.doi.org/10.15809/irriga.2010v15n4p443

SILVA, A.C., et al. Avaliação de linhagens de tomate cereja tolerantes ao calor sob sistema orgânico de produção. Revista Caatinga. 2011, 24(3), 33-40.

SILVA, J.M., et al. Cultivo do tomateiro em ambiente protegido sob diferentes taxas de reposição da evapotranspiração. Revista Brasileira de Engenharia Agrícola e Ambiental. 2013, 17(1), 40-46. http://dx.doi.org/10.1590/S1415-43662013000100006

TAIZ, L. and ZEIGER, E. Fisiologia vegetal. 5th ed. Porto Alegre: Artmed, 2013.

TONFACK, L.B., et al. Impact of organic and inorganic fertilizers on tomato vigor, yield and fruit composition under tropical andosol soil conditions. Fruits. 2009, 64(3), 167-177. http://dx.doi.org/10.1051/fruits/2009012

WANG, X. and XING, Y. Evaluation of the effects of irrigation and fertilization on tomato fruit yield and quality: a principal component analysis. Scientific Reports. 2017, 7(350), 1-13. http://dx.doi.org/10.1038/s41598-017-00373-8

YANAR, D., et al. Effect of different organic fertilizers on yield and fruit quality of indeterminate tomato (Lycopersicon esculentum). Scientific Research and Essays. 2011, 6(17), 3623-3628. http://dx.doi.org/10.5897/SRE10.1083

ZUBA, S.N., et al. Yield and nutrition of tomato using different nutrient sources. Horticultura Brasileira. 2011, 29(1), 50-56.

http://dx.doi.org/10.1590/S0102-05362011000100009

Received: 15 April 2020 | Accepted: 17 December 2020 | Published: 20 January 2021 